\title{
Agricultural Innovation and the Role of Institutions: Lessons from the Game of Drones
}

\author{
Per Frankelius $^{1} \cdot$ Charlotte Norrman $^{1} \cdot$ Knut Johansen $^{2}$
}

Accepted: 7 December 2017/Published online: 29 December 2017

(C) The Author(s) 2017. This article is an open access publication

\begin{abstract}
In 2015, observers argued that the fourth agricultural revolution had been initiated. This article focuses on one part of this high-tech revolution: the origin, development, applications, and user value of unmanned aerial systems (UAS). Institutional changes connected to the UAS innovation are analyzed, based on a Swedish case study. The methods included autoethnography. The theoretical frame was composed by four perspectives: innovation, institutions, sustainability, and ethics. UAS can help farmers cut costs and produce higher quantity with better quality, and also has environmental benefits. However, this promising innovation was exposed to institutional forces and suddenly became subordinated the Act of Camera Surveillance. This study illuminates how legislative institutions can inhibit responsible innovation. The study shows that different ethical perspectives can collide with each other.
\end{abstract}

Keywords Responsible innovation · Unmanned Aircraft Systems · High-tech agriculture

\section{Introduction}

The agricultural sector is under economic pressure due to intense regulation and international competition (OECD and FAO 2016). For individual farmers, this entails demands on efficiency and business development (SOU 2015). The farmer has a dilemma: the mentioned demands require investments. However, the farmers'

$\bowtie$ Per Frankelius

per.frankelius@liu.se

1 Department of Management and Engineering, Linköping University, 58183 Linköping, Sweden

2 Scientific Engineering QED, Onkel Adamsgatan 9, 58235 Linköping, Sweden 
economic capacity for investments might have been reduced because of the economic pressure (Norrman and Svensson 2016).

On the macro level, several challenges of today's societies are related to agriculture (UN 2015). One challenge is greater food needs due to a growing population and changed food consumption patterns, including diet diversifications. In 2014, the United Nations estimated that "food production will need to increase from the current 8.4 billion tons to almost 13.5 billion tons a year" 2050 (FAO 2014 , p. 6). Another challenge is sustainability, not least environmental protection. On one hand, agriculture can have negative effects on the environment. On the other hand, agriculture can absorb carbon, produce substitutes to fossil-related products, and improve biodiversity (cf. Marousek et al. 2016).

Increasing food production and at the same time taking environmental concern into account is not an easy task. For example, just making minor improvements to existing production methods or efforts among distributors and consumers to decrease food waste are probably not enough. Instead, innovation might be the solution. Agriculture has historically undergone innovation-based revolutions. In 2015, the terms "fourth agricultural revolution" (Lejon and Frankelius 2015) or "agriculture 4.0" (Carl-Albrecht Bartmer, speech at Agritechnica) were proposed. These terms referred to the impact of sensors, satellites, digital technology, and robotics, not least in terms of paving the way for precision farming (Mulla 2013).

One part of this revolution is unmanned aircraft vehicles (UAV) or, when including the whole system, unmanned aircraft systems (UAS). ${ }^{1}$ Schnug et al. (1998) noticed the potential of such technology early-and later observers agree: "UAVs are expected to play an expanded role, complementary to that of satellites and conventionally piloted aircraft in agricultural support" (Herwitz et al. 2004, p. 60). Amico (2017) simply defined UAS as a form of disruptive innovation.

UAS includes opportunities for coping with business competition, environmental challenges such as reducing the ecological footprint of agriculture, and increasing food production (Freeman and Freeland 2014). Despite these benefits, the use of UAS with sensors suddenly became heavily prevented in Sweden in 2016. Similar lines of events have occurred in other countries. We will deepen this story later in the article.

\section{Aim and Research Questions}

The aim of this study is to expand the understanding of how institutional changes can affect innovation related to UAS for agricultural use. The research questions are:

\footnotetext{
1 Some prefer the term unmanned aerial vehicles or unmanned aerial systems; yet another term used is remotely piloted aircraft (or aerial) systems (RPAS). While UAS can include fully autonomous systems, RPAS refers to the use of a distant pilot active in real time. Some prefer "aerial robotics" or "airborne robotics" to underline the autonomous character of modern systems.
} 
(1) How have UAS for agricultural use developed and, especially, what kind of value can UAS provide for farms, food production, and agricultural-related environmental improvements?

(2) What major changes in UAS-related institutions, affecting the agricultural industry, have occurred in recent times and how can such changes affect farms, food production, and agricultural-related environmental improvements?

Regarding institutional changes, we focus on Sweden between 1970 and 2017. The Swedish example is interesting because the progress in UAS arose early (Rydberg et al. 2007) and because institutional changes suddenly formed an obstruction to the UAS-related innovation processes.

\section{Research Approach}

The research approach was triangulation (Webb et al. 1966); that is, combinations of methods to cover different aspects of the phenomenon studied (Campbell and Fiskel 1959). The first method used was autoetnography (Hayano 1979), which implies that scientific knowledge is gained through self-perceived experiences (Ellis 1999). One of the authors of the present article has inside experience from the institutional change processes studied. While we acknowledge that this could imply bias, it has brought first-hand access to data (cf. Gummesson 1988).

The second method was communication with experts. The dialogue started in 2013 and was conducted mainly through 13 co-arranged conferences, a number of study visits, and one in-depth study of a proactive farmer in Sweden. ${ }^{2}$

The third method was a literature study, aiming to collect information about the development of the "agricultural drone revolution" as well as to understand the use and values of UAS. The selection of the literature for the review was made through the Scopus database.

\section{Theoretical Frame}

Our theoretical frame is made up of four perspectives: innovation, institutions, sustainability, and ethical responsibility.

\footnotetext{
2 The conferences included Unmanned Flights in Agriculture and Forestry (Vreta Kloster, May 22, 2014), Agriculture Innovation Day (Ultuna, November 17, 2014), UAS Forum (Linköping, May 19-20, 2015), Conference on Unmanned Flying Systems-Opportunity or Threat? (Linköping, February 25, 2015), Aerospace Almedalen (Visby, July 2, 2015), Sweden Innovation Power, Agritechnica (Hannover, November 8-14, 2015), UAV Forum (Linköping, May 24-25 2016), Smart Farming (Vreta Kloster, September 29, 2016 and Torp, September 30, 2016), The Stenhammar Day (Flen, June 13, 2017), Drone Zone, Elmia Wood (Vaggeryd, June 9, 2017), Almedalen (Visby, July 3, 2017), UAS Forum (Linköping, October 3-4, 2017) and The Agriculture Day, Swedish Parliament (Stockholm, November 21, 2017).
} 


\section{The Innovation Perspective}

The departure of the innovation theory discussion, used in this article, is an etymological analysis about the innovation concept. Following a study on how the concept of innovation was originated (Frankelius 2009), it can be concluded that the term innovation could be understood as something new with high originality (principally new), that has obtained a foothold in the community (often via the market), and has appeared at a specific point (or over a specific period) of time. ${ }^{3}$

Many authors have defined innovation as being something "new" (cf. OECD 2005), but "new" is an unspecific term. There are many new things presented at fairs, for example, but not all of them are unusual or unfamiliar in principle. Something "principally new", on the other hand, is something that is new and at the same time includes a character or concept that has not previously been experienced, hence it is closely related to the term that we prefer in this article; namely originality. We define originality as something principally new (Frankelius and Norrman 2013).

Obtaining a foothold is about how users adopt the new concept (Tarde 1890). If this occurs on the market, the phenomenon is called commercialization (Ross 1920; Jolly 1997). Based on the above, the four-field matrix in Fig. 1 could be constructed.

According to Fig. 1, cell 1 represents creations such as inventions or other kinds of principally new ideas or concepts; that is, new products (or services) that have the potential to become innovations partly because of their high level of originality. ${ }^{4}$

Following the definition above, the new creation must first gain ground, either through internal implementation (Salter 1960) or on the market (Schumpeter 1934) in order to enter cell 2 and thereby become an innovation. This means that marketing and customer demand are often central aspects of innovation (Foxall 1984). Information channels and linking mechanisms such as the press, networks, and trade fairs also play a crucial role. The barriers between cell 1 and 2 could be related to the industry, institutions, entrepreneurial attitudes, or the market (Norrman et al. 2015). The present study has focused on the institutional barriers.

The third cell represents insignificant phenomena from an innovation point of view, and the fourth cell represents the majority of products and services including so-called incremental innovations (cf. Rosenbloom and Christensen 1994) and imitations (Tarde 1890) — which, by definition, should not be regarded as a fullfledged innovation due to the lack of originality.

The creation of something original can be done through "new combinations" (Schumpeter 1934). However, as Usher (1929) has shown, novelty creation is much more complicated than just "to combinate things" on some abstract level. Creation processes are complex struggles over time. Moreover, innovation often appear in "swarms" (Schumpeter and Opie 1934, p. 223).

\footnotetext{
${ }^{3}$ This study was further developed in Frankelius (2015) where the innovation concept was applied to agricultural history.

${ }^{4}$ Among practitioners, however, phenomena in cell 1 are quite often regarded as full-fledged innovations. For example, see Agritechnica (2017), which awards innovation prizes only if the preferred candidates are "fully functional at the time of the exhibition and ready for market launch at the latest in 2018". This means that some of the prize-winning concepts are not yet commercialized.
} 
Fig. 1 Two dimensions for defining innovation

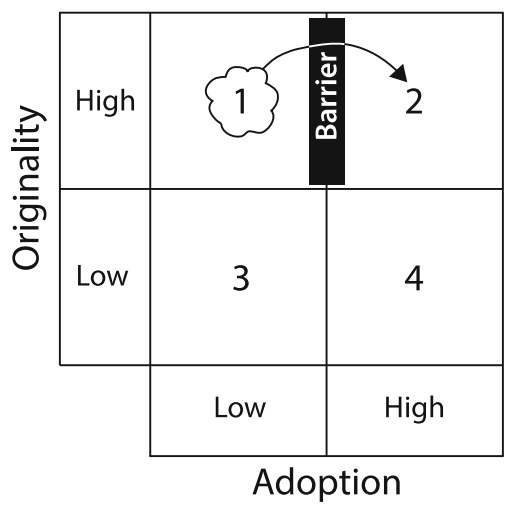

While looking at innovation from an adoption point of view, it is hard to overlook Roger's (1962) diffusion theory. Like his forerunners Ryan and Gross (1943), Rogers gained inspiration from farming life. He verified Tarde's (1890) notion that diffusion of innovations is slow in the beginning and then accelerates. The drawback of his model is that it assumes no other barriers than information about the new, and the behavior of potential adopters.

The learning point regarding innovation is that fulfilling innovation is a matter of two dimensions: original creation and adoption (followed by diffusion).

\section{The Institutions Perspective}

Institutions can be defined as "the rules of the game in society" (North 1990, p. 3). The institutional theory that we build on has its roots in North and Thomas (1973), who argued that institutions, especially the protection of property rights, can explain the progress of most countries of Western society (which was their study object) from 900 to $1700 \mathrm{AD}$. They described the economic impact of political and social institutions including property rights, and human cognition.

The institutional theory that took off from North and Thomas treated institutions as dynamic phenomena. Some of the institutional changes are fueled by ethical or value-related premises (North 2005). Institutions can be changed not only by "power actors" such as governments, but also by whoever is affected upon them. For example, when farmers find that institutions inhibit their business, they could join together and try to change the institutions. North (1991) summarized the definition of institutions as "the humanly devised constraints that structure political, economic and social interaction" (p. 97) and wrote that they "consist of both informal constraints (sanctions, taboos, customs, traditions, and codes of conduct), and formal rules (constitutions, laws, property rights)" (ibid). Institutions also include organizations such as courts.

The notion we derive from this theory is that institutions are dynamic and as important as innovative entrepreneurs and adopters. If institutions change in terms of scope or priorities, consequences will follow. The quality of institutions (Aron 2000) is a matter of perspective. Institutional changes sometimes stimulate innovation, and 
sometimes they inhibit or become complete barriers for it. Moreover, one can look at a certain innovation as good or a threat (Colson 1974; Posner 1980).

\section{The Sustainability Perspective}

The sustainability perspective was fueled by Brundtland (1987), who regarded sustainability as a combination of economic, social, and ecological dimensions and ended up with the following definition: "Development that meets the needs of the present without compromising the ability of future generations to meet their own needs" (p. 26). The Brundtland report was partly based on Brown (1981). According to Brown, the actions on an aggregate level by the rising world population were capable of causing huge changes in the natural systems. He argued that the security and well-being of mankind was threatened.

Two learning points can be derived from the sustainability perspective: first, the ecological dimension is central to all development; second, there are connections between ecology, economy, and social issues. Because of these connections there is a need for alignment between the three dimensions in order to promote sustainability.

\section{The Ethical Responsibility Perspective}

The ethical perspective relates to issues such as responsibility towards different interests in society as well as freedom (Hutcheson 1725). This, in turn, is related to what Holtug (2002) called "harm principles", meaning that the state may coerce a person only if doing so prevents harm to others.

In an analysis of responsible innovation, Hellström (2003) emphasizes the importance of investigating risks on systemic level. By means of agro-industry cases, e.g. mad-cow crisis, he proposes investigation of "the impact of "negative synergies' between complex technologies, social institutions and critical infrastructures" (p. 369). A recurrent theme in this ethics-related literature is that societal and environmental concerns are or should be connected to innovation (Nordgren 2012; Attfield 2014; Lubberink et al. 2017; Long and Blok 2017). Thus, responsible innovation is related to the sustainability perspective (The European Commission 2011; Blok and Lemmens 2015). Therefore, the concept of responsible innovation can be defined as "taking care of the future through collective stewardship of science and innovation in the present" (Stilgoe et al. 2013 p. 1570).

Innovation processes are strongly related to knowledge creation (Nonaka and Takeuchi 1996), hence knowledge management is a prerequisite for the conduct of a responsible innovation process (see e.g. Lubberink et al. 2017). Stilgoe et al. argue that responsible innovation actors should embed anticipation, reflexivity, inclusion, and responsiveness in their management of innovation processes.

"Early stages" can be analyzed at the level of specific innovation process and at the level of a whole industry. According to Stilgoe et al. (2013) anticipation (e.g. forecasts and assessments) and reflexivity (e.g. management principles such as codes of conduct and multidisciplinary collaboration) hence become central activities. Regarding the industry level, Brey (2012) claims that it is important to 
consider the ethical issues in emerging industries; this is because emerging industry formation is often connected with innovation in some way. Brey proposed a framework for anticipatory ethics and suggested that investigations should be done at three levels. The first is the technology level; Brey wrote: "ethical analysis focuses on features of the technology at large, particular subclasses of it, or techniques within it" (p. 8). The second is the artifact level, where "ethical analysis focuses on types of artifacts and processes that have resulted or are likely to result from a particular technology" (ibid). The third level is application, in which the investigator "focuses on particular ways of using an artifact or procedure, or on particular ways of configuring it for use" (ibid). Brey recommended analysis on each of these levels before reaching conclusions.

Pandza and Ellwood (2013) connected to the risk perspective as presented by Hellström (2003), but chose the term uncertainty and related that to research groups engaging in innovation. They proposed that responsible innovation should incorporate both ethical and strategic decisions. Not surprisingly, they found that responsibility was perceived more problematic (among research teams) if "relations between action and impact are characterized by high uncertainty" (p. 1112). A way to deal with this is, as suggested by Stilgoe et al. (2013), to adopt an inclusive approach and let different stakeholders become parts of the process. This is also stressed by Lubberink et al. (2017) who put forward the importance of deliberation.

Blok (2017) summarized responsible behavior (which can include innovation) at two levels from a normative point of view, and with help from Austin's (1961) speech act theory. First, organizations should take responsible concern when thinking about what to do. Second, they should not only think and talk about this, but also transform the mental processes into concrete actions. Ultimately, responsiveness (which includes institutional matters such as regulations, standards, laws, and stage-gate procedures) is about actions-e.g. to behave in a responsive way towards different stakeholders. What Blok related to private corporations is just as relevant for public organizations.

To sum up, our selected part of the ethics perspective circles around the term responsible innovation. This is about knowledge management and includes anticipation, reflexivity, inclusion/deliberation, and responsiveness. The main learning points are that it is valuable to (a) incorporate ethical issues at early stages of innovation processes, (b) apply a holistic perspective that incorporates all levels of analysis.

\section{A Brief History of Aircrafts in Agriculture}

Unmanned aerial vehicles and systems around them made their breakthrough in agriculture around 2011 (Frankelius 2013). This was most likely because the equipment became affordable and easy to use. ${ }^{5}$ Over the next 5 years, the revolution

\footnotetext{
5 The main reason why it was easy to use was automatic control of flights through electronics such as gyros, and electrical motors instead of fueled engines. A related reason was the development of electrical batteries with high power to weight ratios, enabling acceptable flight times (more than $5 \mathrm{~min}$ ).
} 
became intense. However, it all started way back in time. In this section we present some milestones in the development and illustrate different applications.

The use of heavier-than-air aerial vehicles in agriculture probably started in 1921 when the US Agriculture Department, in cooperation with the US Army Signal Corps's research station at McCook Field (Dayton, Ohio) used airplanes to spread pesticide (Johnson 2002). The method was called crop dusting. Although researchers became interested in aerial photos at an early stage for crop analysis (Taubenhaus et al. 1929), this was only research and was not adopted by professional users.

In 1939, airplanes were used to spread seed alongside fertilizers in New Zealand. This project was led by the Royal New Zealand Air Force and the Ministry of Public Works (Campbell 1948). Over the following decades, airplanes became common in agriculture. When helicopters entered the scene, this paved the way for new kinds of applications. In 1978 the farmer Robert Seesholtz in Bloomsburg, US hired manned helicopters to whisk down warmer air over his strawberry fields during the night because the temperatures were close to freezing point at the ground level (Gettysburg Times 1978).

These examples were about manned aircraft not controlled from the ground. One pioneering step in the use of (partly) unmanned vehicles in agriculture probably came in 1906, when John Chaytor, a New Zealand farmer, spread grass seed in a wet valley on the family farm Marshlands in Wairau, Marlborough, using a hot air balloon controlled by ropes from the ground (Alexander and Tullett 1967).

Thanks to a patented invention by Nikola Tesla in 1898, ropes could later be replaced by radio wave-based system. Tesla wrote in his patent that he "designates any type of vessel or vehicle which is capable of being propelled and directed, such as a boat, a balloon, or a carriage." ${ }^{\circ}$ This was written before airplanes and helicopters, and we now know it took a long time to develop radio-controlled (RC) helicopters and airplanes and turn them into professional tools. Dieter Schlüter created a model RC helicopter kit in 1970. One early account on camera equipment was by Thurling et al. (1985), who wrote: "A lightweight radio-controlled model aircraft fitted with a gimbal-mounted $35 \mathrm{~mm}$ camera has been used to obtain very detailed vertical photographs of oilseed rape-weed competition experiments" (p. 357).

In 1987, Yamaha presented the R-50, which it described as "the first practicaluse unmanned helicopter for crop dusting" (Yamaha 2017). However, this version was still a test platform. In 1989, a commercial version of the R-50 entered the market. This machine was complicated to handle and fell under the international arms regulations because of its weight. Users were not allowed to buy one of their own; instead, Yamaha chose to lease them to users and the package included education.

In 1991, the Swedish University of Agricultural Sciences (SLU) started a project to develop an airplane with camera for mapping crop trials (Andersson 1993). The Hungarian engineer Laslo Kiss built a methanol-driven RC-plane that was

\footnotetext{
${ }^{6}$ Method of and apparatus for controlling mechanism of moving vessels or vehicles. US Patent 613,809 , by Nikola Tesla, 1898, p. 4.
} 
approximately $3 \mathrm{~m}$ broad and weighed $17 \mathrm{~kg}$. Anders Larsolle commented: "We made the first tests in 1992 with infrared photography applied on late blight in potato" (personal communication). ${ }^{7}$

Precision agriculture (or farming) became the foremost application area for unmanned aircrafts in agriculture (Rokhmana 2015). The concept is about adjustment of actions and timing to different spots in each field, since the fields are heterogenous regarding many aspects. Field maps containing different information are therefore central. Just as important as information is variable rate technology, which enables machines to act upon detailed field segment information.

Precision field data can be collected by use of sensors mounted on a tractor or other ground vehicle or by handheld instruments. UAS became an efficient new method for gathering data, as it is cheap, reliable, and avoids negative soil compaction.

According to Ulrik Lovang at the agronomic advisor firm Lovang Lantbrukskonsult, UAS-based field data can be used in several ways: Crop color can reveal nutritional deficiencies and diseases or insect attacks. Biomass measurements can enable analysis of yield potential and nutrient requirements to improve harvest. Crop monitoring enables estimations of optimum seed rate, sowing depth, nitrogen supply, and weed control. Lovang concluded: "Compared to treating the whole field in the same way one saves both the environment and costs" (personal communication).

Pioneering experiments were conducted at the University of Bourgogne in France 2001. Jean-Baptiste Vioix recalled:

We used a radio-controlled aircraft equipped with a camera to fly over the fields. Then we scanned the films. We had no digital equipment at the time, it was some simple color films not NIR films. Image processing algorithms were used to separate the plants from the soil and separate crops vs. weeds using the repetition of seeding lines. (personal communication)

Some early adopters brought the new innovative concept into practical use. Robert Blair, at the Three Canyon Farms in Idaho was one. In 2004 he had an insight: "I flew in a small plane over my farm for the first time realizing images were the missing part for precision agriculture. I didn't know it at the time, but this was called remote sensing" (personal communication). In 2006 he noticed an ad in the agricultural magazine CropLife for a farm-adjusted UAS solution called CropCam from Winnipeg, Canada. Blair invested in an UAS and started to operate the fixed wing unmanned aircraft the same year. He commented: "Looking back it's both scary and exciting how that advertisement changed my life and my family's life forever. Crazily blessed and I still have the magazine." (ibid)

In 2009, the Centre for Field Robotics developed an unmanned fixed-wing plane for a test at a cattle farm in western Queensland, Australia (Adams 2013). The project was funded by Meat and Livestock Australia, and its aim was to detect and

\footnotetext{
7 SLU had earlier than this tried to take photos by means of a manned aircraft. The problem was that one needed to fly so close to the ground. After a fatal accident July 12, 1990, that method was abandoned. This event shed light over one advantage with UAS: Less risk.
} 
map weeds that invade trees at the property. The fixed-wing aircraft could fly autonomously by means of GPS and the data was computer-processed so that different tree species and weed attacks were put on a map. After the mapping, an unmanned helicopter was used for spraying herbicide on the red spots on the map. Besides weeds, they also tested to detect locust swarms.

Another application was the use of ground robots parallel to UAS for monitoring almond trees. This project was funded by the Australian Almond Board in 2013, with the purpose of crop estimation by the use of sensors. A helicopter provided a reference to each tree that was scanned. The flowers on the tree were seen as an indicator of the coming almond harvest. The business advantage included better planning of sales contracts. Tim Orr, at the farm Lake Cullulleraine Almonds, commented: "Knowing this early, it gives you a chance to adjust your nutrition program, and if you're going to be forward-selling any products, you know what you may have available for sale" (cited by Adams 2013). In retrospect, however, Orr concluded: "Unfortunately, the project was not as successful at crop estimating as we had hoped it may be" (personal communication). ${ }^{8}$

At Lars Askling's farm Tegneby, Sweden, UAS were tested for organic farming in 2012. The mission was to map root weed, especially thistles (Ståhl et al. 2013).

In 2013, Medins Maskin, Sweden, acquired a radio- as well as GPS-controlled helicopter for preparing and documenting cover drainage. Markus Medin explained: "The GPS receiver allows the helicopter to fly a pre-programmed route and then land within $40 \mathrm{~cm}$ from where it started automatically. I follow the camera images live on a monitor from the ground or in videogoggles." (personal communication)

The shape of modern UAS applied in agriculture varies depending on the application area. In precision agriculture, the core application is to collect, process, and use data about the fields. In Fig. 2, the symbol (a) represents a sensor kit, preferable RGB camera alongside a multispectral sensor, and a light sensor. LIDAR (laser), thermal infrared and hyperspectral sensors are also possible. A gimbal with gyro for stabilization (b) is used for sharper images. The aircraft (c) can be fixedwing or a helicopter and the system includes automatic flight control and planning software, computer GPS location memory, and more. Precision maps (d) are at the heart of the system, and advanced farmers also use big data processing services (e), which combine many data sources and use data algorithms and geostatistics tools. Some systems also use artificial intelligence. The farm's decision maker(s), with or without agronomic advisers (f), both analyze and prescribe actions, partly by help of mobile devices. One action tool is prescription files to machines (g) that can receive and respond to these files. The farmer(s) sometimes also integrate data from satellites, weather stations, soil sensors, or other sources (h) and these data may feed the big data processing and/or the precision maps. The dotted lines in Fig. 2 represent the farm communication system including low-power wide-area networks (LPWAN) for the "Internet of Things," as well as solutions for big data transfer.

\footnotetext{
${ }^{8}$ Instead, another application of UAS appeared to be much more interesting. Orr explained: "Bird control is a major issue with almonds, we use scare guns, reflective strips, horns, shotguns and have used a manned airplane on several occasions. We tried using an inexpensive remote controlled drone and had reasonable good success with it, but soon realized that we would need a more expensive unit that can fly a pre-programmed GPS flight" (personal communication).
} 


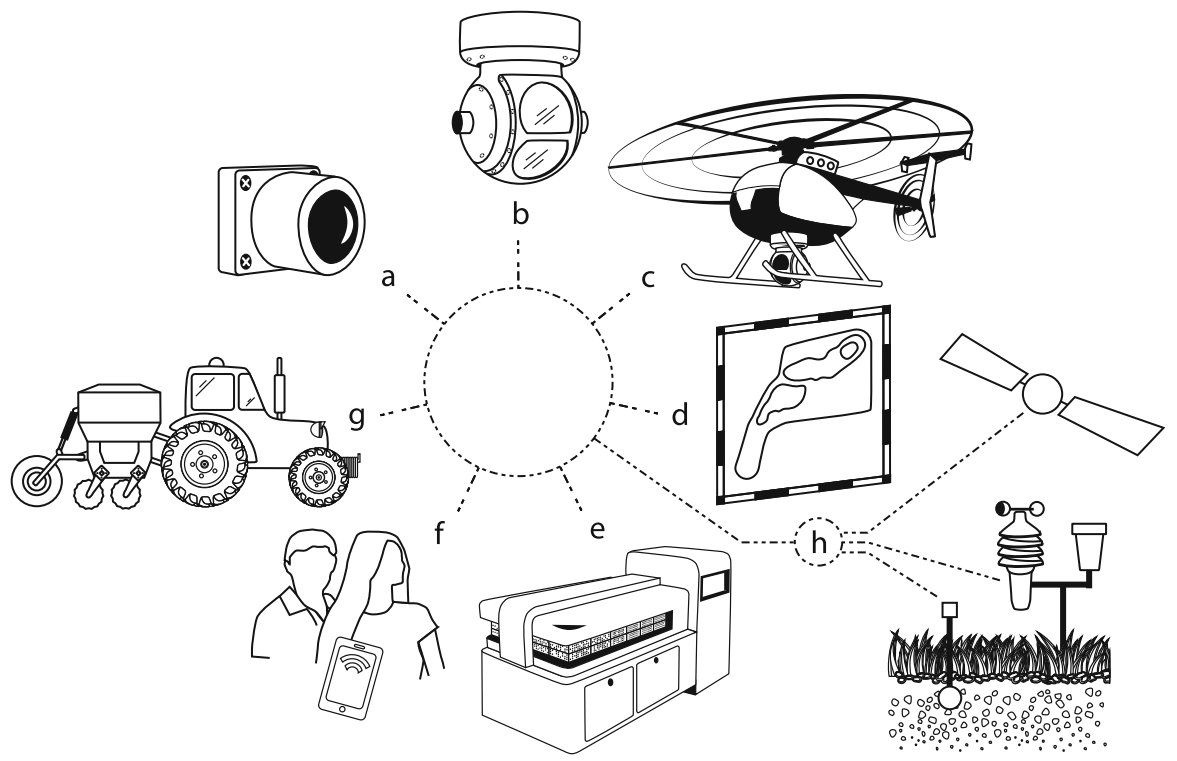

Fig. 2 UAS and related resources for high-tech precision agriculture

\section{Application Areas and User Value Today}

Although modern UAS is a recent phenomenon, many applications have already developed. Some applications have more or less been "researchers playing around," while others have represented professional use among farmers.

\section{Overview of UAS Applications in Agriculture}

Most of the studies that mention UAS applications refer to precision agriculture and crop management in general (cf. Huang et al. 2013; Anderson 2014; Floreano and Wood 2015; Rokhmana 2015). However, besides agronomical applications UAS are also used alongside video cameras for marketing purposes, such as making videos on machinery, e.g. Väderstad. Moreover, UAS have been used to produce empirical descriptions of innovation (Grönovation 2015). In Table 1, application areas found in the literature are defined in more detail and divided into three types. The references given are just examples.

There are more applications of drones in agriculture than those shown in Table 1. Examples include the estimation of phosphorus leakage or analysis of the bearing capacity of pastures. 
Table 1 Literature review of UAS application areas in agriculture

Application area Academic reference

Type A-remote sensing

Analysis of moisture pattern on fields (i.e. water management)

Analysis of soil profiles

Creation of 3D land models and other documentation of land conditions (geo-data)

Yield forecast

Analysis of nutrient profile; e.g. nitrogen

Analysis of weed presence

Analysis of plant health, fungus abundance, etc.

Cattle monitoring and inventory

Identifying wildlife (appearance) and wildlife damage

Inspection of farm houses, plants and other infrastructure such as roads, pipes, drainage and electric lines (various sensors)

Disaster management; e.g., storms, tornadoes, fire, Freeman and Freeland (2016) and floods

Type B-physical actions

Pollination

Spraying herbicides/pesticides, and fertilizers

Seed sowing

Frost protection

Protecting crops from wild animals including birds-"scarecrow"

Type C-marketing, research and media

Marketing campaigns, photos and films for farms, machinery, etc.

Making documentary films about agriculture and demonstrating research
Berni et al. (2009), Martínez et al. (2017), Herwitz et al. (2004)

Capolupo et al. (2014), Schnug et al. (1998)

Obanawa et al. (2014), Freeman and Freeland (2014), Nex and Remondino (2014)

Yang et al. (2015)

Lelong et al. (2008), Bendig et al. (2014)

Berni et al. (2009), Pena et al. (2013), Martínez et al. (2017), Rydberg et al. (2007), Rasmussen et al. (2013)

Martínez et al. (2017), Prakash et al. (2014)

Nyamuryekung et al. (2016)

Mulero-Pázmány et al. (2015)

Kaamin et al. (2016), Mader et al. (2016)

Abutalipov et al. (2016)

Zhou and He (2016), Zhu et al. (2010), Faiçal et al. (2014)

Campbell (1948)

$\mathrm{Hu}$ et al. (2015)

Hahn et al. (2016)

Cajzek and Klanšek (2016)

Few sources found, Hoyos (2003) focus on film industry

\section{User Value on Farm Level: The Wrams Gunnarstorp Case}

One way to understand the value of UAS from a farmer's point of view is to look into a concrete user case. ${ }^{9}$

Wrams Gunnarstorp is a large estate in Skåne, Sweden. The Tornerhjelm family took over the business 1995 and runs it with an inspector and six employees. The farm is modern and includes extensive forestry, hunting, a biogas plant, facility management, and conferences. The Christmas Fair at the castle annually attracts

\footnotetext{
9 The following case study is mostly based on Rudolf Tornerhjelm (personal communication from May 24, 2016 to November 21, 2017), including site visits.
} 
10,000 visitors. The estate incorporates 793 hectares of farming land, half of which is used for winter wheat. Other crops are spring wheat, hybrid barley, peas, oats, sugar beet, oilseed rape, and fescue grass. The farm has also hay fields, meadows, and forest land of 1835 hectares. Besides this, Wrams Gunnarstorp has 1600 pig places, and the manure is used for the biogas plant before it is spread in the fields with a self-propelled hose layer.

In 2005, Sweden was hit by a storm that destroyed 75 billion cubic meters of forest (Joshi Surendra, personal communication). Similar storms appeared in the following years. These events led to Rudolf Tornerhjelm's interest in UAS, and he bought his first system in 2011:

An important part even now was to get an overview. I used a UAS to show the insurance company but also to provide a basis for planning for the staff who would venture into the area. It is extremely dangerous to go into the stormfelled forest, where uprooted trees and partially fallen trees are major risk factors.

Tornerhjelm was concerned about soil compaction: "The worst thing you can do is to disadvantage the land by going out with heavy machinery when it is wet." By use of sensors on the aircraft, maps of the moisture level in the fields can be created. These maps support decisions about when to go out and what vehicle to use. A related application area for UAS is decision support for drainage. Tornerhjelm said: "We had problems with damage as a result of machine loads. Thanks to the images the whole drainage system could be detected. That gave the board of the company decision support regarding the correct drainage strategy." See Fig. 3.

The ability to assess crop yield at upcoming harvests is demanded by many farmers. Tornerhjelm uses the aircraft sensor data to make accurate predictions: "Two months before the harvest, I can demonstrate the need to adjust the forecast. It can lead to discussions with the bank."

Attacks on crops of various kinds, especially snails, are a scourge. UAS images help Tornerhjelm to see exactly where the snails have attacked and then adjust snail poison to each segment. UAS can also be used with regard to attacks from larger animals such as wild boars. Tornerhjelm reflected on a severe situation in 2005: "It was not much left of the wheat. I could show it through my pictures taken with the UAS." The UAS photos were important in communication with the insurance company and for dialogue with hunting tenants and neighbors.

Special sensors enable Tornerhjelm to analyze the nutritional profile of various field segments, by which he can adjust the amount of fertilizer. As an example, he realized that there was too much fertilizer along the ditches. In 2016, Tornerhjelm established a partnership with the company Drone Deploy in San Francisco. He explains: "We take pictures with our UAS in the fields and send the sensor data to Drone Deploy. They then analyze it and include a 'Normalised Difference Vegetation Index', which is sent back to Wrams Gunnarstorp and becomes the basis for programming the fertilizer spreader." By transferring the UAS information to his $36 \mathrm{~m}$ broad self-propelled Sands Agricultural Machinery fertilizer, he can adjust the action specifically for the nitrogen and phosphorus needs of each field segment. The principle is shown in Fig. 4. 


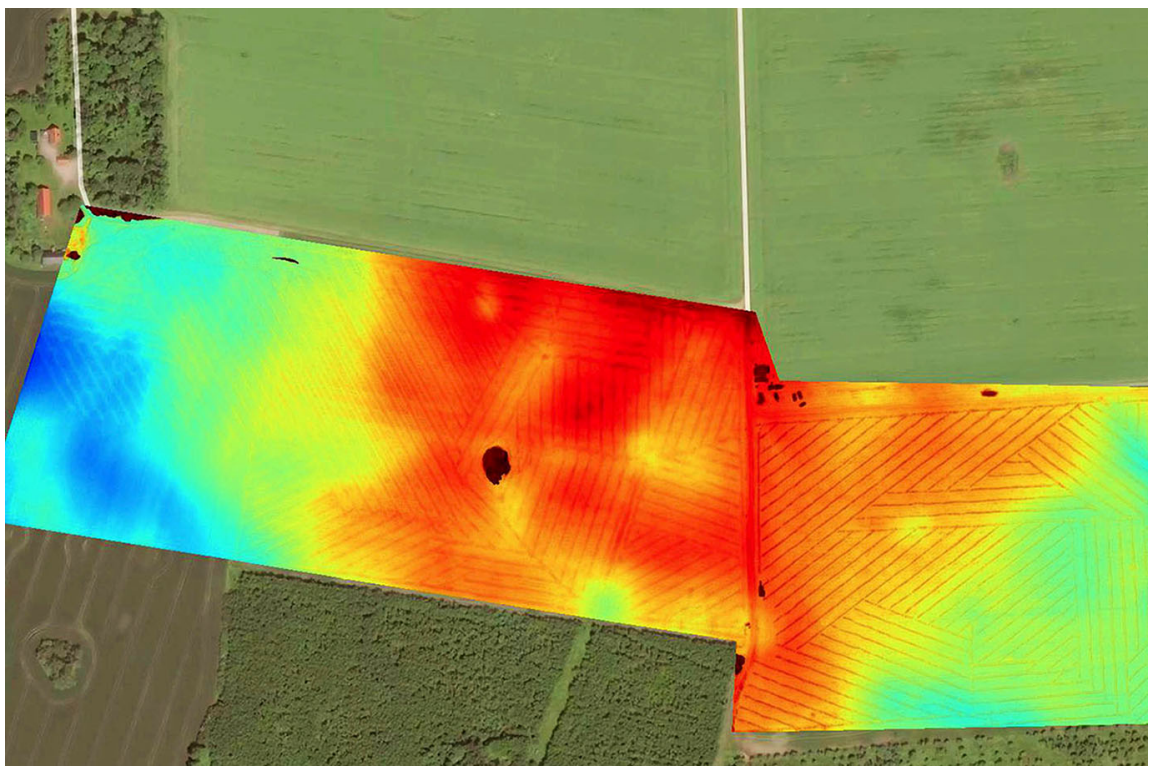

Fig. 3 Sensor data from Wrams Gunnarstorp showing nutrition differences and drainage system (image courtesy of Rudolf Tornerhjelm)

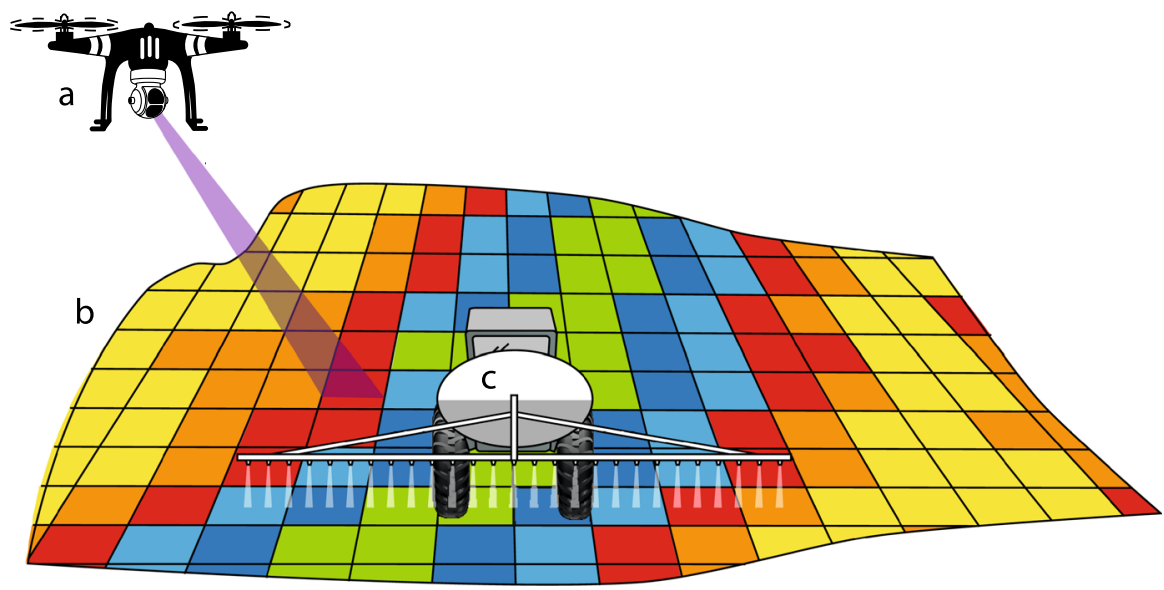

Fig. 4 The drone-based fertilizing solution at Wrams Gunnarstorp

Figure 4 shows the UAS with a sensor (a), scouting the fields. The UAS information processed creates maps (b) that build the basis for prescription files that guide the fertilizer (c). The colors in this map illustrate different nutrient profiles on each field segment. Green indicates a perfect level, blue means too much fertilizer and red-to-yellow means lower levels. 
On a monitor in the farm's command center, various information can be exposed. This is also where the important decisions are made, sometimes together with the board. The information from the UAS undoubtedly contributes to the decision making.

Farmers are exposed to scrutiny and allegations from the authorities. UAS images were used, for example, when the provincial administration, in line with its strategy of "biodiversity", questioned Tornerhjelm's company. Here he could use aerial photos to show the authorities that his father in the 1990s had planted oak trees to increase biodiversity. UAS is also used to, for example, document how the fertilizer went over the bar relative to ditches and buffer strips. Thus, Tornerhjelm can protect his company from false claims by the authorities.

In connection with the planning of a land area that included a lake, Tornerhjelm used his UAS again. Through images, he could get the exact mapping of encroachment during different parts of the year. Furthermore, the UAS has been used to inspect the need for repairs to the castle. Tornerhjelm also uses the UAS to guide the public when visiting his property. "We have 300 hectares allocated for public visitors. Then it is good to be able to offer people images were riding tracks, jogging trails, etc. are available."

Tornerhjelm argued that UAS are important in modern agriculture. He explains that the new high-tech philosophy requires large investments and that there are traps: "To know which sensors to use is not easy." Business intelligence plays a significant role and Tornerhjelm admits that he reads a lot, especially from the Internet. In June 2017, for example, he was interested in the new Slantrange multispectral imaging sensor system.

\section{Visions for Tomorrow}

At the InterDrone fair 2017, the Intelligent Energy company presented a drone with hydrogen cells by which flight time can increase threefold compared with standard batteries. At the Agritechnica fair 2017 the Insensive company showed a drone with power supplied not by batteries but by a wire from a vehicle such as a tractor. Drones will develop, and so will also sensors and system components.

By means of hyperspectral remote sensing, it is possible to detect things such as blight disease in an early stage of its development (Zhang et al. 2003). When the price on these sensors goes down, adoption will accelerate.

Researchers have succeeded in determining soil properties even when the vegetation covers the soil (Ben-Dor et al. 2002). It is probable that UAS also will map what is under the ground surface. SAAB has developed radar equipment that might detect water, stones, or different soil profiles (Lars Sjöström, personal communication). The Danish company SkyTEM has a technique that involves a manned helicopter equipped with an induction magnetometer that can detect water under the ground. In the future this may be a UAS application.

In the fall of 2017, Agrocom Polska presented a prototype in which a threedimensional imaging process, including LIDAR, records field damage (caused by e.g. hailstorms) almost on individual plant level. In the near future, UAS may be used to conduct real-time analysis of every plant. Development is also underway to 
make use of hyperspectral sensors such as Glana for large-scale individual plant phenotyping (Åke Sivertun, personal communication). By use of robotic groupthink algorithms, we will see swarms of drones working together. In Italy and France, for example, research is ongoing to use biomimicry methods inspired by bees.

The massive amounts of data need to be analyzed in the best way. Cognitive computing will develop; for example, in 2016 IBM and SLU started a project to detect downy mildew by means of artificial intelligence provided by the Watson supercomputer.

The combination of drone-sensor data and other kinds of data, such as satellite, machine, weather and ground sensor data, will pave the way for bringing precision agriculture to higher levels. Cloud-based data fusion platforms like the one from CyStellar are already under way.

The huge amounts of data used in agriculture also have to be transferred quickly, easily, safely, and over long distances, which means that big data transfer is another key area. Companies like Signiant have already developed farming solutions for gigabytes transfer.

One vision is to use UAS to detect effort-needs and then let ground-based robots make the necessary interventions. Already in 2010, a research project on this topic was initiated by Aalborg University and University of Copenhagen. Magnus Sundstedt at DST Control provided equipment and said, "We integrated the Mini MCA sensor from Tetracam into our gimbal" (personal communication). Through six sensors the UAS could inspect a sugar beet field and identify specific weeds. Subsequently, small ground-based robots could fight these weeds selectively. The concept is still far from commercialization. ${ }^{10}$

In the future, there will be robust UAS that can function autonomously even at night. They will probably also make interventions directly from the air. Saga University and OPTiM (Japan) are working on a vision of selective spraying or fertilizing. They have also tested the use of UV bug zapper to catch insects on rice fields. Drone4agro in the Netherlands started in 2015 to develop UAS with payload of $100 \mathrm{~kg}$ that can spray $5 \mathrm{ha}$ at a time. During spray missions, "when tank is empty, it returns to the docking station, fills and charges and then resumes mission" (Win Rijssenbeek, personal communication).

In some cases, agricultural uses of drones have synergies with wildlife care. In 2017, for example, the German hunter Rupprecht Walch announced via Facebook that he had rescued 61 fawns on agricultural fields in an 11-day trial by means of UAS. ${ }^{11}$ This innovation may diffuse on a broad basis in the future. ${ }^{12}$ Approximately 100,000 fawns are killed in Germany every year by agricultural machines.

\footnotetext{
${ }^{10}$ In the Greenovation project at Linköping University it was suggested in May 2014 to use UAS in combination with mechanical knives/scissors to handle weed, surgically and without pesticides.

11 Roe deers tend to hide their fawns in high grass fields, as predators usually stay in the woods. When the farmer's grass-cutting machines come closer the fawns become paralyzed and lay still, meaning they will be bad injured or killed. Moreover, when dead animals become part of the silage, bacteria form, which in the next step can cause major diseases for livestock and horses eating the feed.

12 An alternative method is Sensosafe from Pöttinger, presented in 2017. In this method, infrared sensors with integral LED lights are mounted on a grass-cutting machine.
} 


\section{Institutional Change: The Case of Sweden}

In Sweden, some institutional actors, including universities, stimulated the adoption of UAS early. SLU, for example, conducted research on applications in the 1990s. In 2005, experiments began with the SmartOne aircraft. The aim was to produce field maps of weeds or differences in plant nitrogen content (Olle Hagner, personal communication). The JTI institute, SLU, and the Lantmännen company financed the project. SmartPlanes brought the concept to market in 2008. Another example is Vinnova innovation agency, which supported the test platform "Sweden Drone Center". Other actors, such as Vreta Kluster, AgroÖst and UAS Forum, stimulated the development by organizing conferences.

Regarding legislation institutions, Sweden's first rules for UAS were set down in 2009 by the Transport Agency. Professional UAS users required permission from the Agency. Like all aircraft pilots, unmanned aircraft "pilots" had to take into account control zones (areas around airports) and protected areas (military objects etc.). Permission for using UAS in control zones could be obtained from the Air Traffic Control. The Transport Agency's UAS strategy stated that they wanted to stimulate innovation (Gunnar Ljungberg, personal communication).

In 2014 the Swedish Data Protection Authority, or DPA (Datainspektionen in Swedish), entered the scene and presented new ideas regarding camera surveillance rules. The background is summarized below.

During the mid-1970s there were discussions in Sweden regarding the use of surveillance cameras, possible infringements on the freedom of citizens, and how it could be prevented. Consequently, a camera surveillance law-the Act of Camera Surveillance-was introduced in 1977. Only cameras that were placed to surveil a specific area for an extended time, rather than those operated on site, were considered as surveillance cameras. Such cameras needed permission from the authorities, and permission was only given if the camera's purpose was to avoid accidents and crime.

On July 1, 2013, the old camera surveillance law was superseded by a new Act of Camera Surveillance called "KÖL". The two laws are identical in most aspects concerning camera surveillance but one important change was that the DPA was given the responsibility for supervising camera surveillance. The application of the old Act of Camera Surveillance had not encountered any problems over 40 years, but after mid-2013 the DPA started to claim that all cameras that were not handheld should be considered surveillance cameras. At the same time, however, the DPA also claimed that the Act of Camera Surveillance only applied to cameras that were stationary (Datainspektionen 2013). The DPA's opinion seems to have changed between mid-2013 and mid-2014.

One of the DPA's first formally recorded viewpoints that cameras on drones should be considered as surveillance cameras was a letter dated September 19, 2014. The same viewpoint appeared in an article published in the DPA's magazine Integritet $i$ fokus (Datainspektionen 2013) in the fall of 2014. The media now started to publish articles promoting DPA's opinion about cameras, probably unaware of the potential consequences of the uncritical reporting. 
The DPA, as the newly appointed supervising authority, informed the County Administrative Boards (Länsstyrelser in Swedish), which during the fall of 2014 eagerly tried to convince anyone, who would be interested in using a drone with a camera for commercial use, to apply for camera surveillance permission.

Despite there being approximately 400 professional drone operators with a certificate in October 2014, very few applied for permission. Two applications, "Edberg" in Östergötland (October 13, 2014) and "MarknadsTing" in Skåne (December 22, 2014), led to court cases. Edberg was a retired 70-year-old man with a one-person company who was taking airborne still pictures of buildings and landscapes. He had neither the will nor the resources to fight in court.

Despite the fact that the County Administrative Boards have for many years had a policy of not giving permission for surveillance cameras for purposes other than avoiding crime and accidents, they eagerly wanted Edberg to apply for permission. The reason for Edberg to contact the County Administrative Board, was that a journalist had called him and asked if he had a permission for camera surveillance.

The key issue was whether a camera on a drone is a surveillance camera. On February 25, 2015, the County Administrative Board decided that it is. Edberg did not obtain permission to use his camera drone. Edberg was sad and frustrated. However, after reading an article in the local newspaper, Knut Johansen at Scientific Engineering QED offered Edberg help with an appeal. Johansen regarded it as an easy case, so the case was appealed to the Administrative Court (Förvaltningsrätten), which in April 24, 2015 came to the conclusion that Edberg's camera was in fact not a surveillance camera.

The DPA, as a third party, appealed to the Administrative Court of Appeal (Kammarrätten) on May 13, 2015. The Administrative Court of Appeal gave a verdict December 15, 2015, which surprisingly went against the Administrative Court and came to the conclusion that the camera should be regarded as a surveillance camera. The verdict was based on the fact that a camera on a vehicle (bus and taxi) had previously been regarded as a surveillance camera (surveilling persons inside a vehicle), and that the camera was not handheld. The Administrative Court of Appeal did not consider the cumulative necessary prerequisite in the law"can be used for person recognition" - and did not try the constitution. Moreover, it did not consider the exception for cameras on unmanned airborne vehicles, despite it being clearly shown in the legislative history of the law.

Already in May 2015 the drone community had been informed at the drone conference UAS Forum about the DPA's opinion regarding the Act of Camera Surveillance, and the problems that may arise. However, very few thought this could be a reality. The general opinion was: "it is so ridiculous that it can't be true". Almost no one acted to promote the court case or perform any lobbying activity, even though they were continuously informed about the critical situation.

The Edberg case was appealed to the Supreme Administrative Court (SAC) January 2016, which granted leave to appeal on March 23, 2016. In May 2016 a new UAS Forum was held and the drone community was again informed about the catastrophic scenario if the DPA's opinion was accepted in SAC, but this did not lead to any action from the participants. On September 15, 2016 the case was introduced to the judges of SAC, who delivered a verdict on October 21 stating that 
the actual drone camera is a surveillance camera. Surprisingly, especially because the verdict would be precedential, SAC motivated the verdict very rudimentary and did not present valid references to sources of law. Moreover, the constitution was not considered, even though it was the main argument of Edberg's legal representative from the beginning in 2015 .

Because the case set a precedent, all camera drones became, in practice, involved. It is notable that no major agriculture organization, such as the Federation of Swedish Farmers (FSF), was interested in helping Edberg with the court case, even though the applications in agriculture would be heavily affected by the verdict. The reason for FSF not supporting the case was: "Edberg is no member of FSF, and it is a non-prioritized field" (Anders Johannesson, personal communication).

Following the SAC verdict, the drone community was shocked. Companies and politicians started to call for a new law. In the following turbulence, the DPA faced pressure to find ways to overcome the consequences of the SAC verdict. Therefore, on November 16, 2016, the DPA sent instruction to the County Administrative Boards, where the DPA claimed that it is not impossible to get permission for camera surveillance. DPA extended the legal criteria, which had previously stated that the only permitted application was "avoiding crime and accidents". The DPA now extended the law as much as possible, or even longer, and, for example, argued that agriculture may use drones, although it added: "if not for profit, and with large restrictions". What the DPA did not mention in the instruction was how firmly KÖL restricted the handling of material from camera surveillance; for example, material should only be handled by a very restricted group (typical maximum three persons) performing the surveillance (and, as shown, it was DPA that considered it surveillance). Furthermore, the material has to be destroyed within 2 months if not decided otherwise by the County Administrative Board. Not following KÖL could lead to 1 year in prison and liability to pay damages. Therefore, it can be a legal and monetary risk to operate a camera.

Interestingly, some County Administrative Boards extended the permission to commercial use and unlimited time-extending the law. However, Edberg did not get any permission, despite the information from DPA.

The protests continued and the community's voice was heard: on December 20, 2016 the government proposed a new law excluding all non-authority drones from KÖL; in other words, drones could be used without any camera regulation. However, this proposal also meant, unintentionally, that for first time in 40 years, cameras (on drones) could be used for very sensitive camera surveillance-without any regulation. The law proposal was sent for referral with February 13, 2017 as the time limit. Because it would be possible to perform unregulated real camera surveillance of sensitive areas, it is not surprising that the law proposal encountered major criticism.

However, after some negotiation between the two major political blocks, the parliament voted on June 20 for an amendment to KÖL, where drones were unconditionally omitted from the surveillance law, authorities excluded. The vote for the new law received 100 percent support and the law was activated on August 1,2017 . In principle, however, the authorities stated that a camera on a drone is a 
"surveillance camera", despite the fact that most such cameras are not used for "surveillance of people".

After the parliament's decision in June, many magazines sent the message that it was now legal to use drones with sensors and cameras. However, this is not the end of the story. A new camera surveillance law is expected already on May 25, 2018, to harmonize with EU regulation, and the process will be in full swing again. Only time will tell how this ends.

\section{Analysis}

We have shown that UAS-based concepts emerged through the interplay between developers and users in different parts of the world. The drone industry is a result of converging industries; a "crossing-point between the aviation, computing, data communications and robotics industries" (Clark and Bennett Moses 2014, p. 280). As for emerging technologies in general, we have shown that experimentation and re-combination resulted in a diversity of shapes and applications. Schumpeter and Opie's (1934) concept "swarms of innovations" seems to describe the development well.

UAS concepts were novel and had a high degree of originality. Therefore, together with the footing on the market, UAS concepts qualify to be judged as an innovation (cf. Frankelius 2009). Early adopters (Rogers 1962) such as Wrams Gunnarstorp played an important role in the development and evaluation of applications and as role models for others. Farmers are generally conservative (Norrman and Svensson 2016), so role models are important as proof that the new technology is worth staking for. Both literature review and empirics show that

UAS can help farmers cut costs and produce higher quantity with better quality, thus contributing to economic sustainability. On an aggregate level, UAS enhances food production, which entails benefits from a social perspective. UAS can probably also contribute to the image of the farm business, which can promote social sustainability in the countryside (cf. Hemmerling et al. 2012). By implementing precision agriculture, the environment also becomes a winner; for example, farmers can reduce chemicals. Hence UAS fit well with all three of Brundtland's (1987) sustainable dimensions.

The diffusion of UAS concepts in agriculture differs among countries, both in terms of time and magnitude. The Swedish case illustrates how the innovation process was affected by both stimulation and inhibition factors and how the institutional forces created dynamics over time. Figure 5 presents a model that includes some of these stimulators and inhibitors.

The media, trade fairs, and conferences all acted as stimulators. However, some media and conferences also played inhibitor roles. From an institutional perspective, one factor that inhibited the process was the Swedish DPA's initiative (alongside the court decisions).

The banning proponents in Sweden referred to hypothetical integrity infringement; that is, they focused, from an ethics point of view, on one narrow perspective (individual integrity). The proponents of free (responsible) use referred to the need 


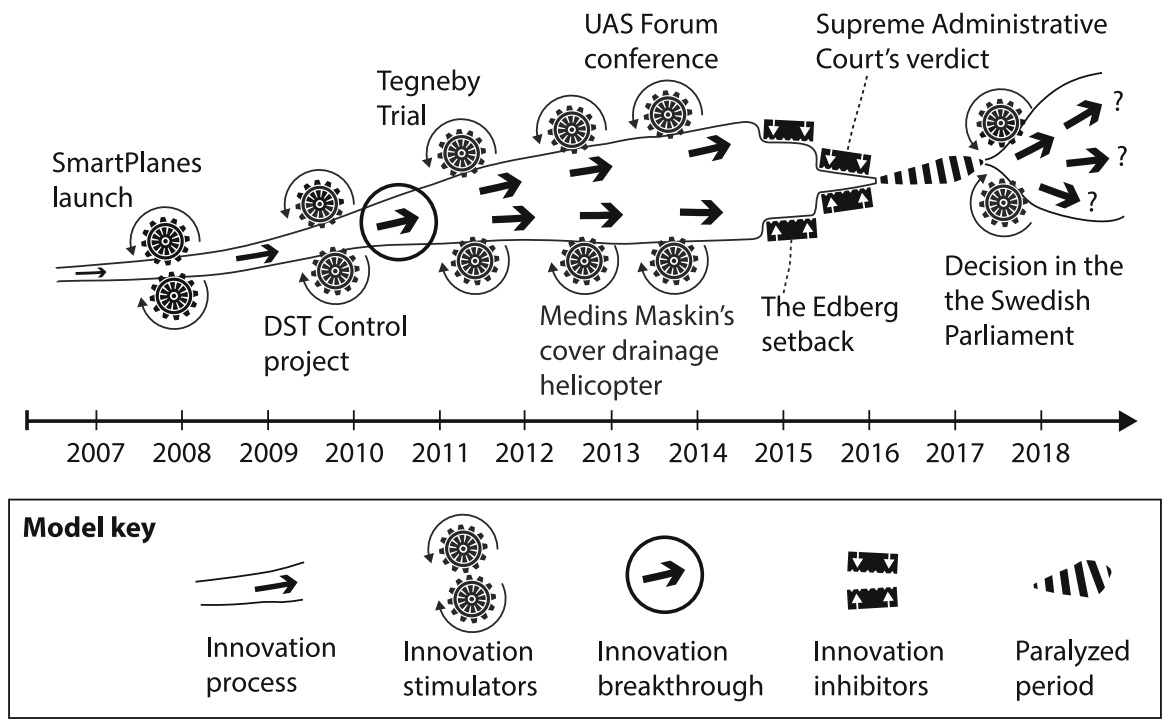

Fig. 5 A model of the UAS innovation process

for business protection, economic development, and environmental concern. Through the UAS case, we have witnessed a collision between different ethical viewpoints. Through the DPA's action, farmers were hindered from applying UAS with sensors. Following the reasoning by Blok and Lemmens (2015), this created a barrier for responsible innovation from an ecological perspective since UAS are connected with precision agriculture and the aim to reduce environmental impact of agriculture. Moreover, according to North and Thomas's (1973) theories, the ban was an encroachment on farmers' property rights.

Although there have been various ethical evaluations of the usage of drones, most of these evaluations have, as far as we can see, been made on what Brey (2012) defined as the technology and artifact levels. Few investigations seem to have been conducted on the application level.

According to Stilgoe et al. (2013), responsibility is a matter of collective stewardship. Therefore, regarding innovation, we argue that the stewardship lies on many parties-especially the innovators, adopters, and institutions-and must therefore be inclusive in its art. Hence, as Stilgoe et al. suggests, all parties have a responsibility that includes anticipation, reflexivity, inclusion and responsiveness, and as highlighted by Lubberink et al. (2017), this must be part of the knowledge management in an innovation process.

When evaluating a new technology from an ethical responsibility point of view, all of the involved actors should think about the potential consequences of the implementation of the technology. It is also relevant to consider the consequences of renouncing implementation of the new technology. Thus, we agree with Brey (2012), who argued that new technology must be thoroughly evaluated from many angles and from a sustainability perspective. Most of the ethical studies on UAS have focused on technology level and on the the negative dimensions, such as 
safety, integrity, security of data/information, dehumanization, and potential misuse (Brennan et al. 2016; Luppicini and So 2016; Clarke and Benett Moses 2014). Our study has focused on the other side of the coin and pointed towards the opportunities this technology offers to address challenges, such as future food production and environmental sustainability. It has also tried to incorporate artifact and application levels into the equation.

\section{Conclusion}

Institutional changes based on a certain ethical logic can affect the development and diffusion of innovation, including UAS. In countries such as Australia and the US, legislative actors struggle with balancing different perspectives in relation to UAS. As we understand it, most country dialogues focus on the balance between promoting the value of UAS and physical safety related to UAS. ${ }^{13}$

The case study of UAS in Sweden illuminates how institutions have interfered in innovation processes, although primarily for integrity reasons rather than safety reasons. Prior to 2016, the regulation related to UAS was mostly about flying security rules and, interestingly enough, the Transport Agency wanted to stimulate innovation. However, changes in the institutional frame occurred and finally, in October 2016, resulted in the UAS becoming subordinated to the Act of Camera Surveillance. This led to uncertainty and problems for farmers and other UAS users, meaning the innovation process was inhibited. However, the rules of the game were changed again in August 2017 through a new law.

Based on this research, the following conclusions can be drawn:

(1) It is fruitful to link theories of innovation to the "Northian" theory of institutions. $^{14}$ Although this link has been addressed before, we have highlighted the interface between the agricultural sector, institutional changes and high-tech innovation.

(2) Institutional changes are connected with ethical perspectives, and some of these can collide with other ethical perspectives. We suggest the term "ethical collisions" for this phenomenon. It was shown that farmers and the environment were the losers of the game that ended up in the court decision in 2016, while the winners were the proponents of hypothetical infringement of individual privacy. The opposite happened thereafter, culminating in the new law in August 2017.

\footnotetext{
13 This, for example, is the main issue in the dialogue around the Civil Aviation Safety Authority (CASA) and the Australian government, which is currently preparing changes to that country's regulatory framework. In the US, work is ongoing at the FFA agency for handling the case of multiple drones operated by a single operator, as well as night operations. This will lead to new regulations for "extended visual line of sight". In France and Switzerland, it is already permitted to fly drones beyond line of sight.

14 The link between institutional change and innovation processes was not evident in North's theory. In personal communication with Douglass North regarding this issue (conducted 2008), he pointed to his book Understanding the Process of Economic Change (North 2005), however, the link to innovation is still not clear. Neither innovation nor invention is even listed in the index of that book.
} 
To promote responsible innovation, societies must take several dimensions into account; however, individual actors in the institutional context tend to focus on just one or a few at a time, because of their narrow scope. While responsible innovation literature has opened our eyes regarding the importance of innovators to apply a holistic approach and be ethically responsible, the present study has illustrated the importance of societal institutions, not least law makers and authorities, to be responsible towards innovators and adopters.

From a policy point of view, our analysis suggest that it is a bad idea to try to stop new technology per se. Instead, specific applications should be focused and, if needed, regulated. Prohibitions and regulations can impede both harmful and beneficial uses. Responsible policy makers consider ethical wisdoms such as the harm principle.

Acknowledgements This project was part of the Greenovation project (Grönovation) at Linköping University. The authors thank Christer Svensson (farming specialist), Urban Wahlberg (Drone Center Sweden) and Rudolf Tornerhjelm (Wrams Gunnarstorp) as well as the Editor and four anonymous reviewers.

Open Access This article is distributed under the terms of the Creative Commons Attribution 4.0 International License (http://creativecommons.org/licenses/by/4.0/), which permits unrestricted use, distribution, and reproduction in any medium, provided you give appropriate credit to the original author(s) and the source, provide a link to the Creative Commons license, and indicate if changes were made.

\section{References}

Abutalipov, R. N., Bolgov, Y. V., \& Senov, H. M. (2016). Flowering plants pollination: robotic system for greenhouses by means of nano copter (drone aircraft). In Proceedings from the 2016 IEEE conference on quality management, transport and information security, information technologies, Nalchik, October 4-11 (pp. 181-184).

Adams, P. (2013). Eyes in the Sky. A film Broadcast by ABC Net, October 19.

Agritechnica (2017). Submission for an innovations award. https://www.agritechnica.com/en/innovationaward/award-criteria/. July 24, 2017.

Alexander, G., \& Tullett, J. S. (1967). Agricultural aviation in New Zealand. Wellington: AH \& AW Reed.

Amico, L. (2017). Ask a drone lawyer. Harvard Business Review. https://hbr.org/2017/05/ask-adronelawyer. December 27, 2017.

Anderson, C. (2014). Agricultural drones. MIT Technology Review, 117(3), 58-61.

Andersson, A. (1993). Pests and diseases. In 34th Swedish Crop Protection Conference, Uppsala, January, 27-28.

Aron, J. (2000). Growth and institutions: A review of the evidence. World Bank Research Observer, 15(1), 99-135.

Attfield, R. (2014). Environmental ethics. Cambridge: Polity Press.

Austin, J. L. (1961). Philosophical papers. London: Oxford University Press.

Bendig, J., Bolten, A., Bennertz, S., Broscheit, J., Eichfuss, S., \& Bareth, G. (2014). Estimating biomass of barley using crop surface models (CSMs) derived from UAV based RGB imaging. Remote Sensing, 6(11), 10395-10412.

Ben-Dor, E., Patkin, K., Banin, A., \& Karnieli, A. (2002). Mapping of several soil properties using DAIS7915 hyperspectral scanner data-a case study over clayey soils in Israel. International Journal of Remote Sensing, 23(6), 1043-1062. 
Berni, J. A. J., Zarko-Tejada, P. J., Suárez, L., \& Fereres, E. (2009). Thermal narrowband multispectral remote sensing for vegetation monitoring from an unmanned vehicle. IEEE Transactions on Geoscience and Remote Sensing, 47(3), 722-738.

Blok, V. (2017). Bridging the gap between individual and corporate responsible behaviour: Toward a performative concept of corporate codes. Philosophy of Management. https://doi.org/10.1007/ s40926-016-0045-7.

Blok, V., \& Lemmens, P. (2015). The emerging concept of responsible innovation. Three reasons why it is questionable and calls for a radical transformation of the concept of innovation. In B. J. Koops et al. (Eds.), Responsible innovation 2: Concepts, approaches, and applications (pp. 19-35). Berlin: Springer.

Brennan, K., Birch, M., \& Stanton, J. (2016). Drones in Australian agriculture and the law. Journal of the Australian \& New Zealand Institute of Insurance \& Finance, 39(3), 1-4.

Brey, P. A. E. (2012). Anticipatory ethics for emerging technologies. Nanoethics, 6, 1-13.

Brown, L. R. (1981). Building a sustainable society. New York: W. W. Norton.

Brundtland, G. H. (1987). Our common future. Oxford: Oxford University Press.

Cajzek, R., \& Klanšek, U. (2016). An unmanned aerial vehicle for multi-purpose tasks in construction industry. Journal of Applied Engineering Science, 14(2), 314-327.

Campbell, D. A. (1948). Preliminary aerial distribution trials with superphosphate and seed mixtures. New Zealand Journal of Science and Technology, 30A, 65-77.

Campbell, D., \& Fiskel, D. (1959). Convergent and discriminant validation by the multitrait-multimethod matrix. Psychological Bulletin, 56, 81-105.

Capolupo, A., Pindozzi, S., Okello, C., \& Boccia, L. (2014). Indirect field technology for detecting areas object of illegal spills harmful to human health: Application of drones, photogrammetry and hydrological models. Geospatial Health, 8(3), 699-707.

Clarke, R., \& Benett Moses, L. (2014). The regulation of civilian drones' impact on public safety. Computer Law \& Security Review, 30, 263-285.

Colson, E. (1974). Tradition and contract: The problem of order (p. 1974). Chicago: Adeline Publishing.

Datainspektionen. (2013). Vad gäller för kameran i mobilen. Integritet i fokus, 3-4, 6.

Ellis, C. (1999). Composing ethnography: Alternative forms of qualitative writing. Ethnographic Alternatives Book Series, V. 1. New York: Altamira Press.

European Commission. (2011). Horizon 2020-the framework programme for research and innovation. Brussels: European Commission.

Faiçal, B. S., Costa, F. G., Pessin, G., Ueyama, J., Freitas, H., Colombo, A., et al. (2014). The use of unmanned aerial vehicles and wireless sensor networks for spraying pesticides. Journal of Systems Architecture, 60(4), 393-404.

FAO. (2014). Building a common vision for sustainable food and agriculture. Rome: FAO.

Floreano, D., \& Wood, R. J. (2015). Science, technology and the future of small drones. Nature, 521, 460-466.

Foxall, G. (1984). Corporate innovation: Marketing and strategy. New York: Routledge.

Frankelius, P. (2009). Questioning two myths in innovation literature. The Journal of High Technology Management Research, 20(1), 40-51.

Frankelius, P. (2013). Satelliter och flyg lyfter jordbruket till nya höjder. In F. Dahl (Ed.), Flyg idagFlygets Årsbok 2013 (pp. 94-131). Flygboken: Stockholm.

Frankelius, P. (2015). Innovationsbegreppet och innovationsindikatorer-En analys med tonvikt på statistikens validitet. Stockholm: Statistics Sweden.

Frankelius, P., \& Norrman, C. (2013). Uppfinningars betydelse för Sverige (VR 2013:03). Stockholm: Vinnova.

Freeman, P. K., \& Freeland, R. S. (2014). Politics \& technology: U.S. policies restricting unmanned aerial systems in agriculture. Food Policy, 49, 302-311.

Freeman, P. K., \& Freeland, R. S. (2016). Media framing the reception of unmanned aerial vehicles in the United States of America. Technology in Society, 44, 23-29.

Gettysburg Times. (1978). Ag-rotors Has Task to Keep Strawberries Warm. Gettysburg Times 76(85), April 17, front page.

Grönovation (2015). Gothia Redskap—ett exempel på innovation inom gröna näringar (https://vimeo. com/138962478, Sept. 11, 2015).

Gummesson, E. (1988). Qualitative methods in management research. Lund: Studentlitteratur. 
Hahn, N., Mwakatobe, A., Konuche, J., de Souza, N., Keyyu, J., Goss, M., et al. (2016). Unmanned aerial vehicles mitigate human-elephant conflict on the borders of tanzanian parks: A case study. Oryx, 51(3), 513-516.

Hayano, D. M. (1979). Auto-ethnography: Paradigms, problems, and prospects. Human Organization, 38, 113-120.

Hellström, T. (2003). Systemic innovation and risk: Technology assessment and the challenge of responsible innovation. Technology in Society, 25, 369-384.

Hemmerling, U., Pascher, P., Nass, N., \& Seidel, C. (2012). Situationsbericht 2012/13: Trends und Fakten zur Landwirtschaft. Berlin: Deutscher Bauernverband.

Herwitz, S. R., Johnson, L. F., Dunagan, S. E., Higgins, R. G., Sullivan, D. V., Zheng, J., et al. (2004). Imaging from unmanned aerial vehicle: Agricultural surveillance and decision support. Computers and Electronics in Agriculture, 44, 49-61.

Holtug, N. (2002). The harm principle. Ethical Theory and Moral Practice, 5(4), 357-389.

Hoyos, C. (2003). Unmanned systems topic. Paper presented at the 2nd AIAA conference and workshop and exhibit, San Diego, September 15-18.

Hu, Y. G., Liu, S. Z., Wu, W. Y., Wang, J. Z., \& Shen, J. W. (2015). Optimal flight parameters of unmanned helicopter for tea plantation frost protection. International Journal of Agricultural and Biological Engineering, 8(5), 50-57.

Huang, Y., Thomson, S. J., Hoffmann, W. C., Lan, Y., \& Fritz, B. K. (2013). Development and prospect of unmanned aerial vehicle technologies for agricultural production management. International Journal of Agricultural and Biological Engineering, 6(3), 1-10.

Hutcheson, F. (1725). Inquiry into the original of our ideas of beauty and virtue. London: J. Darby.

Johnson, M. A. (2002). McCook Field 1917-1927. Dayton, Ohio: Landfall Press.

Jolly, V. K. (1997). Commercializing new technologies: Getting from mind to market. Harvard: Harvard Business School Press.

Kaamin, M., Rahman, M. M. A., Ngadiman, N., Kadir, A. A., Nor, A. H. M., Hamid, N. B., et al. (2016). Visual inspection of historical buildings using unmanned aerial vehicles (UAV): A case study of Sultan Abu Bakar Mosque, Johor. Advanced Science Letters, 22(9), 2160-2163.

Lejon, E., \& Frankelius, P. (2015). Sweden innovation power-Agritechnica 2015. Jönköping: Elmia.

Lelong, C. C. D., Burger, P., Jubelin, G., Roux, B., Labbé, S., \& Baret, F. (2008). Assessment of unmanned aerial vehicles imagery for quantitative monitoring of wheat crop in small plots. Sensors, $8,3557-3585$.

Long, T., \& Blok, V. (2017). When the going get tough the tough gets going: towards new-more critical-engagement with responsible research and innovation in an age of Trump, Brexit, and wider populism. Journal of Responsible Innovation, 4(1), 1-7.

Lubberink, R., Blok, V., van Ophem, J., \& Mota, O. (2017). Lessons for responsible innovation in the business context: A systematic literature review of responsible, social and sustainable innovation practise. Sustainability, 9(721), 1-31.

Luppicini, R., \& So, A. (2016). A technoethical review of commercial drone use in the context of governance, ethics, and privacy. Technology in Society, 46, 109-119.

Mader, D., Blaskow, R., Westfeld, P., \& Weller, C. (2016). Potential of UAV-based laser scanner and multispectral camera data in building inspection. Paper presented at the international archives of the photogrammetry, remote sensing and spatial information sciences-ISPRS Archives, January (pp. 1135-1142).

Marousek, J., et al. (2016). Glory and misery of biochar. Clean Technologies and Environmental Policy, $19(2), 311-315$.

Martínez, J., Egea, G., Agüera, J., \& Pérez-Ruiz, M. (2017). A cost-effective canopy temperature measurement system for precision agriculture: A case study on sugar beet. Precision Agriculture, 18, 95-110.

Mulero-Pázmány, M., Barasona, J. Á., Acevedo, P., Vicente, J., \& Negro, J. J. (2015). Unmanned Aircraft Systems complement biologging in spatial ecology studies. Ecology and Evolution, 5(21), 4808-4818.

Mulla, D. J. (2013). Twenty five years of remote sensing in precision agriculture: Key advances and remaining knowledge gaps. Biosystems Engineering, 114, 358-371.

Nex, F., \& Remondino, F. (2014). UAV for 3D mapping applications: A review. Applied Geomatics, 6(1), $1-15$.

Nonaka, I., \& Takeuchi, H. (1996). A theory of organizational knowledge creation. IJTM, special publication on unlearning and learning, 11(7/8), 833-845. 
Nordgren, A. (2012). Ethical issues in mitigation of climate change: The option of reduced meat production and consumption. Journal of Agricultural and Environmental Ethics, 25(4), 563-584.

Norrman, C., Öberg, C., \& Hult, P. (2015). Barriers to biomedical engineering commercialisation. In A. Groen, G. Cook, \& P. Van Der Sijde (Eds.), New technology-based firms in the new millennium (Vol. 11, pp. 55-72). Bingley: Emerald Group Publishing.

Norrman, C., \& Svensson, E. (2016). Grönovations pargårdsstudie, projektrapport Grönovationsprojektet. Linköping: Linköpings universitet.

North, D. C. (1990). Institutions, institutional change and economic performance. New York: Norton.

North, D. C. (1991). Institutions. The Journal of Economic Perspectives, 5(1), 97-112.

North, D. C. (2005). Understanding the process of economic change. Princeton: Princeton University Press.

North, D. C., \& Thomas, R. P. (1973). The rise of the Western world: A new economic history. Cambridge: Cambridge University Press.

Nyamuryekung, E. S., Cibils, A. F., Estell, R. E., \& Gonzalez, A. L. (2016). Use of an unmanned aerial vehicle-mounted video camera to assess feeding behavior of raramuri criollo cows. Rangeland Ecology and Management, 69(5), 386-389.

Obanawa, H., Hayakawa, Y. S., \& Gomez, C. (2014). 3D modelling of inaccessible areas using UAVbased aerial photography and structure from motion. Chikei/Transactions. Japanese Geomorphological Union, 35(3), 283-294.

OECD. (2005). Oslo manual: Guidelines for collecting and interpreting innovation data (3rd ed.). Paris: OECD and European Commission.

OECD, \& FAO. (2016). OECD-FAO Agricultural Outlook 2016-2025. Paris: OECD Publishing.

Pandza, K., \& Ellwood, P. (2013). Strategic and ethical foundations for responsible innovation. Research Policy, 42, 1112-1125.

Pena, J. M., Torres-Sánchez, J., de Castro, A. I., Kelly, M., \& López-Grandos, F. (2013). Weed mapping in early-season maize fields using object-based analysis of unmanned arerial vehicle (UAV) images. PLOS ONE, 8(10), 1-11.

Posner, R. (1980). A theory of primitive society, with special reference to the law. Journal of Law and Economics, XXIII, 1-54.

Prakash, N. K. U., Vasantharaj, R., Balasubramanian, E., Bhushan, G., Das, S., \& Eqbal, F. (2014). Design, development and analysis of air mycoflora using fixed wing unmanned aerial vehicle (UAV). Journal of Applied Science and Engineering, 17(1), 1-8.

Rasmussen, J., Nielsen, J., Garcia-Ruiz, F., Christensen, S., \& Streibig, J. C. (2013). Potential uses of small unmanned aircraft systems (UAS) in weed research. Weed Research, 53, 242-248.

Rogers, E. M. (1962). Diffusion of innovations. New York: The Free Press.

Rokhmana, C. A. (2015). The potential of UAV-based remote sensing for supporting precision agriculture in Indonesia. Procedia Environmental Science, 24, 245-253.

Rosenbloom, R. S., \& Christensen, C. M. (1994). Technological discontinuties, organizational capabilities, and strategic commitments. Industry and Corporate Change, 3(3), 665-685.

Ross, E. A. (1920). Commercialization-increasing or decreasing? International Journal of Ethics, 30(3), 284-295.

Ryan, B., \& Gross, N. C. (1943). The diffusion of hybrid seed corn in two Iowa communities. Rural Sociology, 8, 15-24.

Rydberg, A., Hagner, O., Söderström, M., \& Börjesson, T. (2007). Obemannad flygfarkost (UAV) överblickar grödorna. Uppsala: JTI.

Salter, W. (1960). Productivity and technical change. Cambridge: Cambridge University Press.

Schnug, E., Panten, K., \& Haneklaus, S. (1998). Sampling and nutrient recommendations-the future. Communications in Soil Science and Plant Analysis, 29(11-14), 1455-1462.

Schumpeter, J. A. (1934). The theory of economic development. Cambridge, Mass: Harvard University Press.

Schumpeter, J. A., \& Opie, R. (1934). The theory of economic development: An inquiry into profits, capital, credit, interest, and the business cycle. Cambridge, Mass: Harvard University Press.

SOU. (2015). Attraktiv, innovativ och hållbar-strategi för en konkurrenskraftig jordbruks- och trädgårdsnäring (SOU 2015:15). Stockholm: Fritzes.

Ståhl, P., Söderström, M., \& Adolfsson, N. (2013). Gradering av rotogräs i ekologisk odling med hjälp av fotografering från obemannat flygplan $(U A V)$. Skara: Precisionsodling Sverige.

Stilgoe, J., Owen, R., \& Macnaghten, P. (2013). Developing a framework for responsible innovation. Research Policy, 42, 1568-1580. 
Tarde, G. (1890). Les lois de l'imitation. Paris: Alcan.

Taubenhaus, J. J., Ezekiel, W. N., \& Neblette, C. B. (1929). Airplane photography in the study of cotton root rot. Phytopathology, 19, 1025-1029.

Thurling, D. J., Harvey, R. N., \& Buller, N. J. (1985). Aerial photography of field experiments using remotely-piloted aircraft. In British crop protection conference, Weeds. Brighton, November 18-21 (pp. 357-363).

UN. (2015). Transforming our world: The 2030 agenda for sustainable development. New York: United Nations.

Usher, A. P. (1929). A history of mechanical inventions. New York: McGraw-Hill.

Webb, E. J., Campbell, D. T., Schwartz, R. D., \& Sechrest, L. (1966). Unobtrusive measures: Nonreactive research in the social sciences. Chicago: Rand McNally.

Yamaha (2017). http://rmax.yamaha-motor.com.au/history. Retrieved February 15, 2017.

Yang, G., Li, C., Yu, H., Xu, B., Feng, H., Gao, L., et al. (2015). UAV-based multi-load remote sensing technologies for wheat breeding information acquirement. Nongye Gongcheng Xuebao/Transactions of the Chinese Society of Agricultural Engineering, 31(21), 184-190.

Zhang, M., Qin, Z., Liu, X., \& Ustin, S. L. (2003). Detection of stress in tomatoes induced by late blight disease in California, USA, using hyperspectral remote sensing. International Journal of Applied Earth Observation and Geoinformation, 4(4), 295-310.

Zhou, L. P. \& He, Y. (2016). Simulation and optimization of multi spray factors in UAV. Paper presented at the 2016 american society of agricultural and biological engineers annual international meeting, ASABE 2016.

Zhu, H., Lan, Y., Wu, W., Hoffmann, C., Huang, Y., \& Fritz, B. (2010). Development of a pwm precision spraying controller for unmanned aerial vehicles. Journal of Bionic Engineering, 7(3), 276-283. 